\title{
Yield and canopy response of chickpea (Cicer arietinum L.) to different irrigation regimes
}

\author{
M. Rinaldi ${ }^{1}$, A. V. Vonella ${ }^{1}$, P. Soldo ${ }^{2}$, G. Debiase ${ }^{1} \&$ P. Garofalo ${ }^{1}$ \\ ${ }^{I}$ C.R.A. - Unità di ricerca per i sistemi colturali degli \\ ambienti caldo-aridi, Italy \\ ${ }^{2}$ Consorzio per la Bonifica della Capitanata, Italy
}

\begin{abstract}
In recent years, the interest for legume crops has been increasing in the European Community, both for the agronomic improvement of soil fertility and for human and animal food source reasons. Chickpea (Cicer arietinum L.) in the Mediterranean environment is not usually irrigated. Knowledge about its canopy growth, water and radiation use efficiencies can improve chickpea productivity. In this study, the chickpea has been submitted to different irrigation scheduling at specific crop phases and as a function of soil moisture. Total plant biomass was related to water availability and radiation interception. But in good conditions of available water there was a lengthening of the crop cycle, with reduction of pod growth, harvest index and nutrient toward the seeds. Consequently, the best values of water use efficiency were found in the treatment irrigated with $50 \mathrm{~mm}$ only at flowering or at pod filling. Protein yield was higher in the treatment refilling field capacity when soil plant available water was $25 \%$. A canopy extinction coefficient of 0.84 and a radiation use efficiency of $1.02 \mathrm{~g}$ $\mathrm{MJ}^{-1}$, on average, were found. In conclusion, the irrigation of the chickpea at sensitive phases (flowering and pod filling) and with a low amount of water, resulted in the best strategies.
\end{abstract}

Keywords: chickpea, water use efficiency, radiation use efficiency, water deficit.

\section{Introduction}

The chickpea is one of the major legume crops grown in Mediterranean regions, where rainfall is highly variable and often insufficient. As the season progresses, the crop is exposed to increasing moisture deficit and heat. This results in low 
and variable yields and discourages farmers from investing in inputs for the crop's production. Limited supplemental irrigation can, however, plays a major role in boosting and stabilizing the productivity of winter-sown chickpea (Zhang et al. [14]). Chickpea has a strong indeterminate growth habit and when growing conditions are favourable the plant continues vegetative growth without setting pods or filling few pods (Davies et al. [2]; Liu et al. [5]). The detrimental effects of drought can be modified to some extent through management options such as irrigation (Soltani et al. [12]). However, in the literature there are differing views on the effect of irrigation timing coinciding with moisture-sensitive periods in chickpea. Some authors (Jadhav et al. [4]) suggest that chickpea is more sensitive to drought during flowering. However, others (Ravi et al. [8]; Reddy and Ahlawat [9]) suggested seed filling as the critical time for irrigation. In contrast, Ramakrishna and Reddy [9] demonstrated a seed yield reduction of more than $50 \%$ in chickpea when they were irrigated due to excess vegetative growth, which leads to lodging. The present study aimed to investigate the effect of supplemental irrigation levels on the phenology, plant growth, yield, seed quality and water and radiation use efficiencies of winter-sown chickpea in Southern Italy.

\section{Material and methods}

\subsection{Experimental site}

The field experiment was carried out in 2006-2007 at Foggia (lat. 41 8 , $^{\prime \prime} \mathrm{N}$; long. $15^{\circ} 83^{\prime} 5^{\prime}, \mathrm{E}$, alt. $90 \mathrm{~m}$ a.s.1.) in Southern Italy. The soil is a vertisol of alluvial origin (Typic Chromoxerert, fine, termic, according to the Soil Taxonomy-USDA), silty-clay with the following characteristics: organic matter, $2.1 \%$; total N, 0.122\%; $\mathrm{NaHCO}_{3}$-extractable $\mathrm{P}, 41 \mathrm{ppm} ; \mathrm{NH}_{4} \mathrm{O}$ Ac-extractable $\mathrm{K}_{2} \mathrm{O}$, $1598 \mathrm{ppm}$; $\mathrm{pH}$ (water) 8.3; field capacity water content $0.396 \mathrm{~m}^{3} \mathrm{~m}^{-3}$; permanent wilting point water content $0.195 \mathrm{~m}^{3} \mathrm{~m}^{-3}$, available soil water $202 \mathrm{~mm}$ $\mathrm{m}^{-1}$. The climate is "accentuated thermomediterranean" (Unesco-FAO classification), with temperatures below $0{ }^{\circ} \mathrm{C}$ in the winter and above $40{ }^{\circ} \mathrm{C}$ in the summer. Annual rainfall (mean $550 \mathrm{~mm}$ ) is mostly concentrated during the winter months and class "A pan', evaporation exceeds $10 \mathrm{~mm} \mathrm{day}^{-1}$ in summer. Daily meteorological data - temperatures, humidity, rainfall, wind velocity and solar radiation - were collected in the local meteorological station.

\subsection{Field experiment}

Chickpea (Cicer arietinum L., cv Pascià, desi type), was sown on $4^{\text {th }}$ December 2006 and different irrigation scheduling were compared:

- $\quad$ A: one irrigation $(50 \mathrm{~mm})$ at flowering;

- $\quad$ B: one irrigation $(50 \mathrm{~mm})$ at pod filling;

- $\quad$ C: irrigation of $40 \mathrm{~mm}$ of water, every time that soil moisture reached the threshold of $25 \%$ of plant available water (PAW) measured with TDR probes at 0-60 cm depths; 
- $\quad$ D: idem at $50 \%$;

- $\quad$ E: idem at $75 \%$;

- $\quad$ Rainfed: a not irrigated control.

To ensure uniform water distribution, a drip irrigation system was used, with one line for each plant row and drippers of $4 \mathrm{~L} \mathrm{~h}^{-1}$ flow. A pre-sowing with $60 \mathrm{~kg}$ $\mathrm{ha}^{-1}$ of $\mathrm{P}_{2} \mathrm{O}_{5}$ as triple perphosphate was applied. A randomised block design with four replications was used; a sowing density of 40 seed $\mathrm{m}^{-2}$ was adopted, with a distance between rows of $0.5 \mathrm{~m}$. Harvest was performed with plot machine harvester, on $4^{\text {th }}$ July 2007 , when the seed moisture content was lower than $13 \%$.

\subsection{Measurements}

The main crop phenological phases were recorded and expressed as degree days (GDD), considering a base temperature of $+2{ }^{\circ} \mathrm{C}$. Soil moisture was measured with TDR probes (25 cm length), placed in the soil at 30,60, and 90 $\mathrm{cm}$ depth, at 1-hour time and daily averaged. Gravimetric soil water measurements were also carried out at 20,40 and $60 \mathrm{~cm}$ depth at sowing, at harvest and at growth analysis sampling dates.

Growth analysis was carried out from March to June; at seven sampling dates, dry matter, separated into stems, green and dead leaves and pods was measured by taking 0.5 linear meter sample from every plot and dried at $80^{\circ} \mathrm{C}$ until weight was constant. Leaf Area Index was determined measuring green leaves area with Delta T Devices (Decagon Devices Inc., WA, USA). At harvest, the total plant dry matter, and the seed yield were determined. Seed nitrogen content was determined using the elementary analyzer Fison CHN (EA 1108). Seasonal water use $(W U)$ was estimated according to the following water balance equation:

$$
W U= \pm \Delta S W C+R+I
$$

where $\triangle S W C$ is the variation, between seeding and harvest date, of the volumetric soil water content in the $0-0.6 \mathrm{~m}$ depth layer, $R$ is the rainfall and $I$ the irrigations, all expressed in $\mathrm{mm}$. Despite the fact that chickpea roots can reach deep layers $(>0.6 \mathrm{~m})$, the presence of a compact calcareous layer reduces the root depth and allowed us to limit at $0.6 \mathrm{~m}$ the depth of soil samples. Water use efficiency (WUE), was determined as the ratio of grain or biomass yield, to seasonal water use. Irrigation water use efficiency (IWUE) was evaluated as being the ratio of the difference in crop yield between irrigated and rainfed plots to the difference in $W U$ for the same treatments:

$$
I W U E=\frac{Y i-Y r}{W U i-W U r}
$$

where $Y$ is the seed or total aboveground biomass yield $\left(\mathrm{g} \mathrm{m}^{-2}\right), W U$ is the seasonal water use (mm), and the subscripts $r$ and $i$ refer to rainfed and irrigated treatments, respectively. Water and irrigation water use efficiency are expressed in $\mathrm{kg}$ per cubic meter and subscript TDM and yield indicated the total dry matter and seed respectively. Radiation use efficiency (RUE $\mathrm{g} \mathrm{MJ}^{-1}$ of $\left.i P A R\right)$ was calculated as slope of regression line between cumulative intercepted 
photosynthetic active radiation $(i P A R)$ and total dry biomass for each sampling (Charles-Edwards [1]). The $i P A R$ was estimated using the following equation:

$$
i P A R=P A R e^{-k L A I}
$$

where $P A R$ is equal to global radiation multiplied by $0.48\left(\mathrm{MJ} \mathrm{m}^{-2} \mathrm{day}^{-1}\right), k$ is the light extinction coefficient, calculated as slope of fitted regression between the natural logarithm of transmitted PAR and LAI, both measured with LI-COR 2000 portable area meter. Global radiation was measured daily with a thermophile pyranometer (305-2800 $\mathrm{nm}$ wave-length range). Analysis of variance of the data was carried out using a "randomized block" design model, and Least Significant Difference was used to compare mean values.

\section{Results and discussion}

\subsection{Growth and yields}

Total dry plant biomass was similar among the irrigation treatments, except in the last two samplings (end of May - beginning of June, Fig. 1a) when higher values were observed in the most irrigated treatments. This is due to an extension of the crop cycle, confirmed by a delayed in flowering and pod filling in D and E treatments (Tab. 1). Table 1 and figure $1 \mathrm{~b}$ show as the irrigation before the flowering (A treatment) delayed the pod appearance, with a reduction of the useful time to mobilize nutrients from leaves and stems towards the seeds. The leaf area index ( $L A I)$ was positively influenced by water availability (Fig. 1c). The irrigation at pod filling (B treatment) favoured a leaf emission and vitality, as shown by an increased $L A I$ after irrigation. Specific leaf area followed the same development of TDM and $L A I$ (fig. 1d) with increased values with water supplies.

Chickpeas irrigated according soil moisture threshold $(\mathrm{C}, \mathrm{D}$ and $\mathrm{E})$ gave similar values of total plant dry biomass at harvest (Tab. 2), higher than A, B and rainfed treatments; this result was similar compared with results reported from Oweis et al. (2004) in a Mediterranean environment. On the contrary, the seed yield resulted greater in the plants irrigated at pod filling and at $25 \%$ of available water, with about $234 \mathrm{~g} \mathrm{~m}^{-2}$ of seeds, while the rainfed and the other irrigation

Table 1: $\quad$ Growth degree days $\left(G D D\right.$ in $\left.{ }^{\circ} \mathrm{C}\right)$ for chickpea development ( $\mathrm{T}$ base $\left.=+2{ }^{\circ} \mathrm{C}\right)$. PAW $=$ plant available water.

\begin{tabular}{ccccc}
\hline Treatment & Emergence & Begin flowering & Pod filling & $\begin{array}{c}\text { Physiological } \\
\text { maturity }\end{array}$ \\
\hline $\boldsymbol{A}=$ flowering & 101 & 1245 & 1449 & 2329 \\
$\boldsymbol{B}=$ pod filling & 101 & 1245 & 1449 & 2329 \\
$\boldsymbol{C}=\mathbf{2 5 \%} \boldsymbol{P} \boldsymbol{A} \boldsymbol{W}$ & 101 & 1284 & 1487 & 2329 \\
$\boldsymbol{D}=\mathbf{5 0} \boldsymbol{\text { PAW }}$ & 101 & 1284 & 1634 & 2412 \\
$\boldsymbol{E}=\mathbf{7 5} \boldsymbol{\%} \boldsymbol{P A \boldsymbol { W }}$ & 101 & 1327 & 1681 & 2490 \\
Rainfed & 101 & 1245 & 1449 & 2249 \\
\hline
\end{tabular}



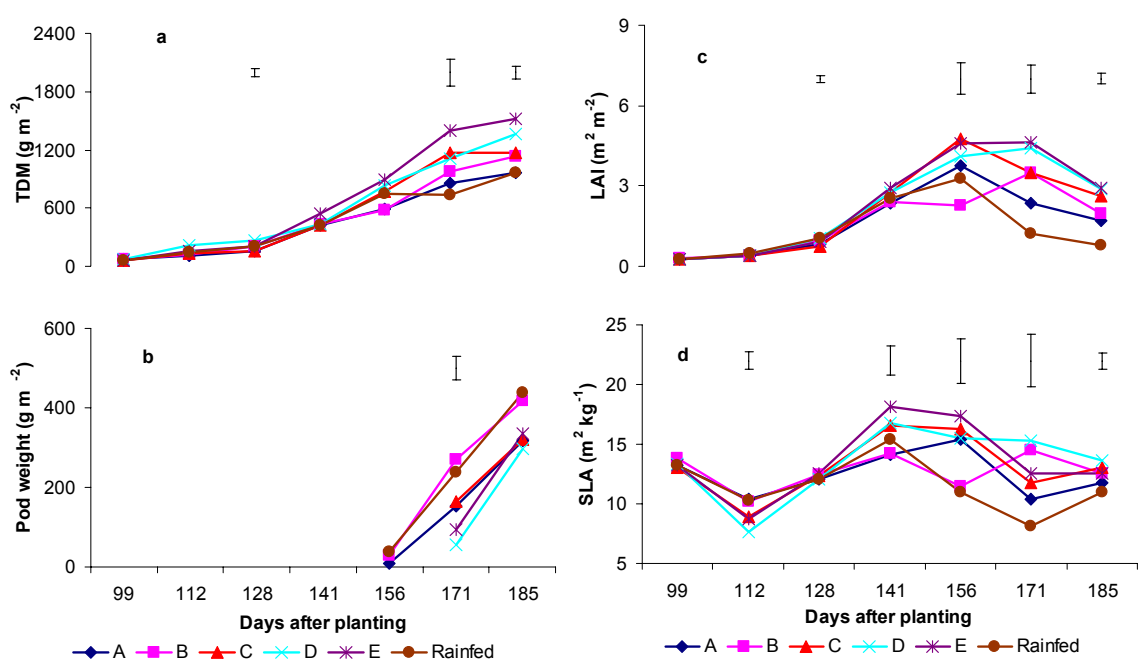

Figure 1: $\quad$ Growth variables for chickpea: (a) total dry matter (TDM), (b) pod weight, (c) Leaf Area Index (LAI) and (d) Specific Leaf Area (SLA). Bars indicate LSD at $\mathrm{P} \geq 0.05$.

Table 2: $\quad$ Main yield results (different letters in each column, indicate values significantly different at $\mathrm{P} \geq 0.05$, LSD test) of chickpea experiment.

\begin{tabular}{|c|c|c|c|c|c|c|}
\hline Treatment & $\begin{array}{l}\text { TDM } \\
\left(g m^{-2}\right)\end{array}$ & $\begin{array}{c}\text { Seed } \\
\text { yield }_{10 \%} \\
\left(g m^{-2}\right)\end{array}$ & $\begin{array}{c}\text { Harvest } \\
\text { Index } \\
(\%)\end{array}$ & $\begin{array}{c}\text { Unit seed } \\
\text { weight } \\
(m g)\end{array}$ & $\begin{array}{c}\text { Protein } \\
\text { content } \\
(\%)\end{array}$ & $\begin{array}{c}\text { Protein } \\
\text { yield } \\
\left(k g h a^{-1}\right)\end{array}$ \\
\hline$A=$ flowering & $678 \mathrm{C}$ & $201.4 \mathrm{~B}$ & $0.27 \mathrm{~A}$ & $516.0 \mathrm{~A}$ & 22.0 & $444.9 \mathrm{ABC}$ \\
\hline$B=$ pod filling & $738 \mathrm{C}$ & $235.7 \mathrm{~A}$ & $0.30 \mathrm{~A}$ & $518.3 \mathrm{~A}$ & 20.1 & $473.5 \mathrm{AB}$ \\
\hline$C=25 \% P A W$ & $1089 \mathrm{~B}$ & $230.9 \mathrm{~A}$ & $0.20 \mathrm{~B}$ & $511.1 \mathrm{~A}$ & 21.5 & $495.8 \mathrm{~A}$ \\
\hline$D=50 \% P A W$ & $1474 \mathrm{~A}$ & $204.7 \mathrm{~B}$ & $0.13 \mathrm{C}$ & $464.7 \mathrm{C}$ & 21.2 & $434.0 \mathrm{BCD}$ \\
\hline$E=75 \% P A W$ & $1439 \mathrm{~A}$ & $199.4 \mathrm{~B}$ & $0.13 \mathrm{C}$ & $454.8 \mathrm{C}$ & 20.3 & $402.7 \mathrm{CD}$ \\
\hline Rainfed & $668 \mathrm{C}$ & $182.1 \mathrm{~B}$ & $0.25 \mathrm{AB}$ & 486.4 B & 21.6 & 392.7D \\
\hline
\end{tabular}

scheduling gave similar seed yield. The seed growth and final size were influenced by the shortening of time from ripening to maturity, with negative effects on seed unit weight, with a value of $459 \mathrm{mg}$ on average for D and E the treatment, in comparison to $515 \mathrm{mg}$ found in the treatments A, B and C (Tab. 2).

Also commercial seed size, influencing the final price, resulted higher in the A, B and rainfed treatments, smaller in E treatment. Seed protein content resulted not different among treatments, with an average of $21.1 \%$, but the protein per hectare yield was bigger in $\mathrm{C}$ than $\mathrm{D}, \mathrm{E}$ and rainfed (Tab. 2). 


\subsection{Evapotranspiration and water use efficiency}

Under supplemental irrigation, seasonal water use increased with the amount of applied water, ranging from $354 \mathrm{~mm}$ in rainfed treatment, to $901 \mathrm{~mm}$ in $\mathrm{E}$ treatment. In treatments based on soil plant available water, the number of irrigation ranged from 3 (C) to 10 (E) (Tab. 3). The large number of irrigation supplies for E treatments is due to lower rainfall supply and higher ETO in this year than long-term values in the period ranging from 50 to 160 days after sowing (Fig. 2).
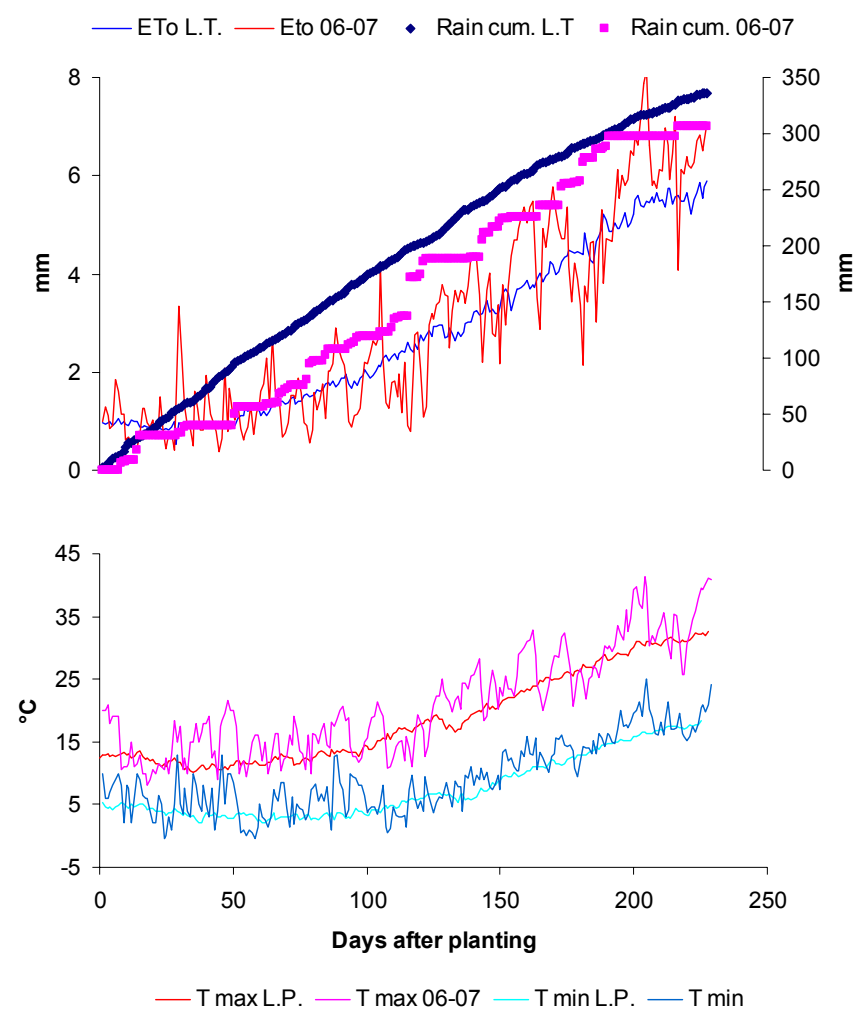

Figure 2: Comparison among some recorded climatic variables during the crop cycle compared with long term (50 years) averages.

Figure 3 shows volumetric soil content at 0-0.3 m soil depth; in A and C treatments the soil moisture fell close to the wilting point, while in D treatment it was higher and more regular. In the final phase of chickpea growth the elevated evaporative demand quickly leaded the soil water content at values lower than the wilting point, also in the well irrigated treatment.

Table 3, shows, except for the treatment $\mathrm{D}$, the values of $W U E_{T d m}$ were similar, with values ranging between 1.6 for $\mathrm{E}$ and $1.89 \mathrm{~kg} \mathrm{~m}^{-3}$ for $\mathrm{B}$ treatment, 
close to those reported by Oweis et al. [6] and Siddique et al. [10]. The irrigation at pod filling resulted the most efficient irrigation scheduling, with $0.55 \mathrm{~kg}$ of grain per cubic meter of water, followed by rainfed and A treatments with 0.50 and $0.46 \mathrm{~kg} \mathrm{~m}^{-3}$, respectively. The lowest values were observed in the treatment with low harvest index. Irrigation at pod filling allowed obtaining best results in term of $W U E_{T d m}$ and $W U E_{\text {yield }}$ similar to those reported by Oweis et al. [6]. The efficiency of irrigation water was on average low for the good performance of rainfed chickpea; it was statistically higher in the B treatment, both for TDM and yield, than the other treatments. Globally, the irrigation at a specific phase resulted more efficient than soil moisture based scheduling.

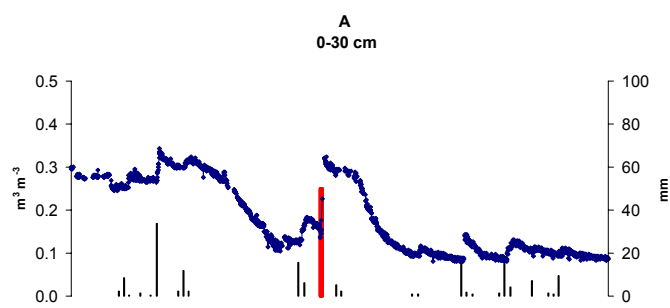

C

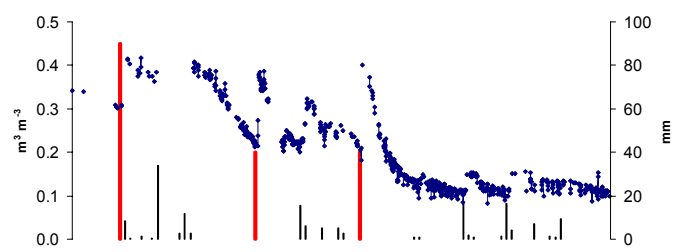

D

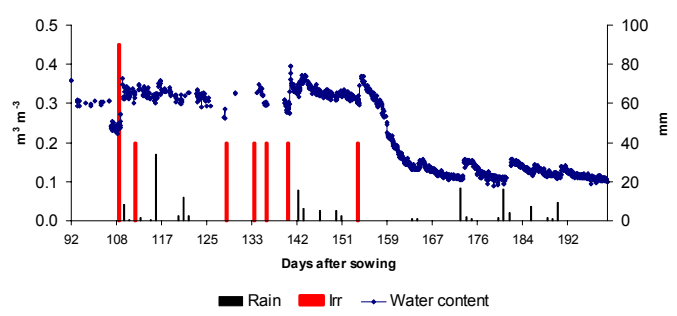

Figure 3: Volumetric soil content at $0-0.3 \mathrm{~m}$ (rhombus) measured with TDR probe, rain (thick column) and irrigation (fine column), for A (irrigation at flowering, at the top), C (irrigation at $25 \%$ of PAW; middle) and D (irrigation at 50\% of PAW; below) treatments. 


\subsection{PAR interception and radiation use efficiency}

The crop cycle duration and canopy growth, increased for the irrigation supply, influenced the leaf area index dynamic and, consequently, the fraction of intercepted $P A R$. In fact, as shown by figures $4 \mathrm{a}$ and $4 \mathrm{~b}$, intercepted $P A R$ declined at the last sampling only in $\mathrm{A}$ and rainfed treatments. The fitted regression between the natural logarithm of transmitted $P A R$ and $L A I$ for all treatments, forced through the origin $(P A R$ above and under canopy are equal

Table 3: Water balance components and water use efficiency (different letters in each column, indicate values significantly different at $\mathrm{P} \geq$ 0.05 LSD test) of chickpea experiment.

\begin{tabular}{|c|c|c|c|c|c|c|c|}
\hline Treatment & $\begin{array}{c}\text { Irrig. } \\
n .\end{array}$ & $\begin{array}{c}\text { Irrig. } \\
\mathrm{mm}\end{array}$ & $\begin{array}{l}\text { Water } \\
\text { Use } \\
\mathrm{mm}\end{array}$ & $\begin{array}{c}\mathbf{W U E} \mathbf{E}_{\mathbf{T d m}} \\
\left(\mathrm{kg} \mathrm{m}^{-3}\right)\end{array}$ & $\begin{array}{c}\mathbf{W U E}_{\text {yield }} \\
\left(\mathrm{kg} \mathrm{m}^{-3}\right)\end{array}$ & 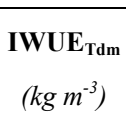 & $\begin{array}{c}\mathbf{I W U E}_{\text {yield }} \\
\left(\mathrm{kg} \mathrm{m}^{-3}\right)\end{array}$ \\
\hline$A=$ flowering & 1 & 50 & 400 & $1.69 \mathrm{AB}$ & $0.46 \mathrm{C}$ & $0.01 \mathrm{C}$ & $0.40 \mathrm{~B}$ \\
\hline $\begin{array}{c}B=p o d \\
\text { filling }\end{array}$ & 1 & 50 & 392 & $1.89 \mathrm{AB}$ & $0.55 \mathrm{~A}$ & $2.10 \mathrm{~A}$ & $1.42 \mathrm{~A}$ \\
\hline $\begin{array}{c}C=25 \% \\
P A W\end{array}$ & 3 & 170 & 520 & $1.55 \mathrm{~B}$ & $0.30 \mathrm{D}$ & $1.21 \mathrm{~B}$ & $0.14 \mathrm{BC}$ \\
\hline $\begin{array}{c}D=50 \% \\
P A W\end{array}$ & 7 & 330 & 685 & $2.15 \mathrm{~A}$ & $0.27 \mathrm{D}$ & $2.44 \mathrm{~A}$ & $0.07 \mathrm{C}$ \\
\hline $\begin{array}{c}E=75 \% \\
P A W\end{array}$ & 10 & 550 & 901 & $1.60 \mathrm{~B}$ & $0.20 \mathrm{E}$ & $1.41 \mathrm{~B}$ & $0.03 \mathrm{C}$ \\
\hline Rainfed & 0 & 0 & 354 & $1.89 \mathrm{AB}$ & $0.50 \mathrm{~B}$ & - & - \\
\hline
\end{tabular}
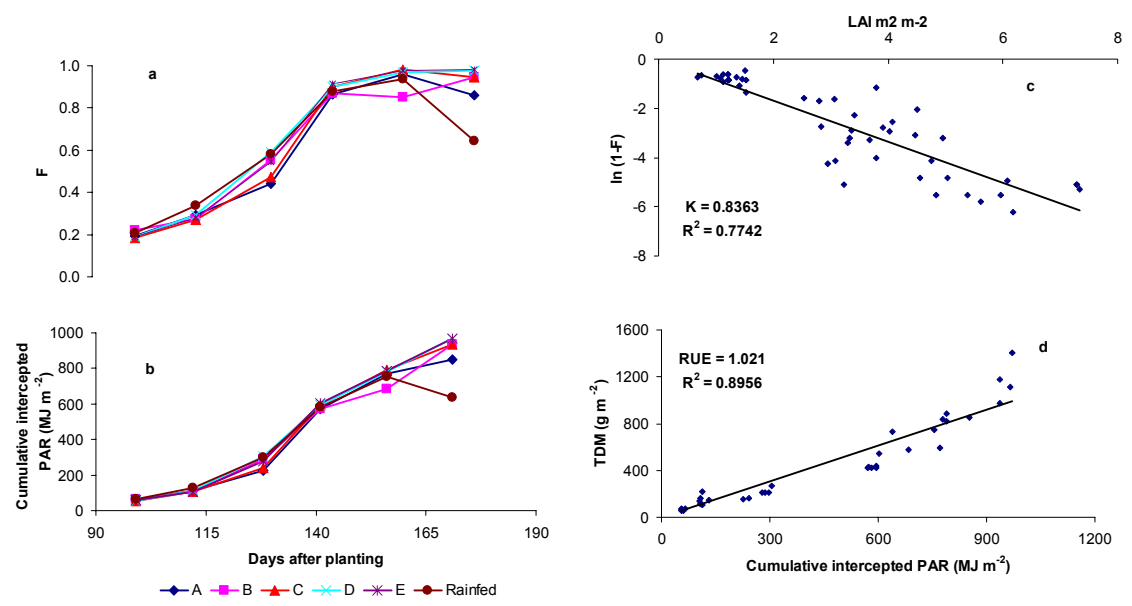

Figure 4: $\quad$ Fraction of intercepted $P A R$ (a), seasonal cumulative intercepted $P A R$ (b), canopy extinction coefficient (c) and radiation use efficiency $\left(\mathrm{g} \mathrm{MJ}^{-1}\right.$ of $\left.i P A R\right)(\mathrm{d})$. 
when $L A I=0)$, allowed us to obtain canopy extinction coefficient $(k)$ as shown in figure $4 c$. This coefficient equal to $0.84\left(\mathrm{R}^{2}=0.77\right)$ is similar to that obtained by Tesfaye et al. [13] in a semi-arid environment, for chickpea submitted to an "irrigation-late stress" treatment. Average chickpea radiation use efficiency (Fig. 4d) resulted equal to $1.02 \mathrm{~g} \mathrm{MJ}^{-1}\left(\mathrm{R}^{2}=0.90\right)$, a low value if compared with $\mathrm{C} 4$ crops, but in the range $0.30-1.68 \mathrm{~g} \mathrm{MJ}^{-1}$ of $P A R$, reported by Hughes et al. [3], Singh and Sri Rama [11] and Tesfaye et al. [13].

\section{Conclusions}

In the farming systems of Mediterranean region, winter-sown chickpea, allows exploiting winter rainfall, saving on water supplying, but maintaining good productive results, as shown by the performances in terms of yield and water use efficiency on rainfed chickpea. However, in experimental season the rainfall was well distributed during flowering and this certainly favoured the yield of rainfed treatment. The results show as large irrigation supply increased seasonal evapotranspiration, but without benefit for seed yield. In fact, soil moisture was similar in the compared treatments (A, C and D); this means that a large developed crop canopy, consumes more water, but with a scarce efficiency in seed yield. The crop plasticity, important for the best adaptation to water deficit conditions, influences also the foliage orientation; in fact, at beginnings of May, when irrigation was suspended, the leaf angling of rainfed treatment resulted superior of 30\% (not shown: measured with LI-COR 2000 area meter) in comparison with $\mathrm{E}$ treatment. This means a more leaf vertical orientation in the rainfed treatment, in response to water deficit, allowing a reduction of leaf exposition to solar radiation and consequently of transpiration; this explains the results in term of $W U E_{T d m}$ and $W U E_{\text {yield }}$ in rainfed treatment.

In conclusion, despite the shortness of the experiment, it has been evident as irrigation of chickpea at specific phases of crop growth (flowering - pod filling) and with small amount of water, could be an agronomical practice to obtain good results in terms of yield, seed quality and water use efficiency.

\section{References}

[1] Charles-Edwards, D.A., 1982. Physiological determinants of crop growth. Academic Press, Sydney, Australia, 161 pp.

[2] Davies, S., Turner, N., Siddique, K., Plummer, J. and Leport, L., 1999. Seed growth of desi and kabuli chickpea (Cicer arietinum L.) in a shortseason Mediterranean-type environment. Aus. J. Exp. Agric. 39: 181-188.

[3] Hughes, G., Keatinge, J., Scott, A., Cooper, J. and Dee, N., 1987. Solar radiation interception and utilization by chickpea (Cicer arietinum L.) crops in northern Syria. J. Agric. Sci. Camb. 108: 419-424.

[4] Jadhav, J., Shewalw, M., Mokashi, D., Gaikwad, C. and Patil, J., 1997. Crop coefficients and actual evapo-transpiration of gram (Cicer arietinum) grown in lysimeter. Indian J. of Agricultural Sciences, 67: 33-35. 
[5] Liu, P., Gan, Y., Warkentin, T. and McDonald, C., 2003. Morphological plasticity of chickpea in a semiarid environment. Crop Sci., 43: 426-429.

[6] Oweis, T., Hachum, A. and Pala, M., 2004. Water use efficiency of wintersown chickpea under supplemental irrigation in a Mediterranean environment. Agricultural Water Management, 66: 163-179.

[7] Ramakrishna, A. and Reddy, S.L.N., 1993. Production potential and economic feasibility of different crop sequences in rice (Oryza sativa) fallows. Indian Journal of Agricultural Sciences, 63: 611-615.

[8] Ravi, N., Sharma, H.M., Singh, R.N.P. and Nandan, R., 1998. Response of late-sown chickpea to irrigation and foliar nutrition in calcareous soil. Journal of Applied Biology, 8: 5-8.

[9] Reddy, N.R.N. and Ahlawat, I.P.S., 1998. Response of chickpea (Cicer arietinum) genotypes to irrigation and fertilizers under late-sown conditions. Indian Journal of Agronomy, 43: 95-101.

[10] Siddique, K., Regan, K., Tennant, D. and Thomson, B., 2001. Water use and water use efficiency of cool season grain legumes in low rainfall Mediterranean-type environments. Eur. J. of Agronomy, 15: 67-280.

[11] Singh, P. and Sri Rama, Y.V., 1989. Influence of water deficit on transpiration and radiation use efficiency of chickpea (Cicer arietinum L.). Agric. For. Meteorology, 48: 317-330.

[12] Soltani, A., Ghassemi, G.K., Khooie, F.R. and Moghaddam, M., 1999. A simple model for chickpea growth and yield. Field Crops Research, 62, 213-224.

[13] Tesfaye, K., Walker, S. and Tsubo M., 2006. Radiation interception and radiation use efficiency of three grain legumes under water deficit conditions in a semi-arid environment. Europ. J. Agronomy, 25: 60-70.

[14] Zhang, H., Pala, M., Oweis, T. and Harris, H., 2000. Water use and water use efficiency of chickpea and lentil in a Mediterranean environment. Aust. J. Agric. Res. 51: 259-304. 